\title{
Exogenous Model of Job Satisfaction
}

\author{
Igor A. Shevchuk and Tatyana B. Melnikova* \\ Department for Management, Tourism and Hospitality \\ Plekhanov Russian University of Economics, Sevastopol Branch \\ Sevastopol, Russian Federation
}

Received 07.09.2019, received in revised form 02.12.2019, accepted 12.12.2019

\begin{abstract}
The paper contributes to the existing job satisfaction models by introducing a new exogenous variable, regional tourism development. Tourism does not only change the regional economy and infrastructure; it creates new cultural practices, causes the change in the attitude to health and leisure, presents a different model of judgement and decision-making. Consequently, it may be suggested that the tourism development rate influences the behaviour model of the local residents. It is proposed to identify the changes based on two-stage modelling with the help of multiple linear and non-linear regression. At the first stage, the relationship between tourism development and cultural practices, as well as between tourism development and quality of life are investigated on the basis of objective data. Low tourism growth rates provoke an increase in both cultural practices and quality of life; however, in the future, at medium growth rates, motivated convictions begin to form dissipated ideas of leisure in the residents' behaviour. At the second stage, the residents' self-assessment was applied to build overall and exogenous models of job satisfaction. The influence of the exogenous variable decreased the impact of the material factor (salary satisfaction) on job satisfaction, forming a new attitude to leisure, and, therefore, causing changes in the people's psychological well-being. The results revealed that one's own sense of sufficient labour-leisure balance decreases as the tourist traffic increases, and the social comparison effect is triggered. Besides, at the high tourism growth rates, habituation to the tourist traffic and regularly updating leisure programmes develops the adaptation effect, which is manifested in the enhanced work schedule satisfaction influencing the job satisfaction.
\end{abstract}

Keywords: job satisfaction, tourism, economic behaviour, cultural practices, exogenous model, leisure, health, labour productivity, work schedule, resident.

Research area: economics.

Citation: Shevchuk, I.A., Melnikova, T.B. (2020). Exogenous model of job satisfaction. J. Sib. Fed. Univ. Humanit. Soc. Sci., 13(5), 818-830. DOI: 10.17516/1997-1370-0529.

\footnotetext{
(C) Siberian Federal University. All rights reserved

* Corresponding author E-mail address: sevastopol@rea.ru ORCID: 0000-0002-2639-498X (Melnikova)
} 
Introduction. In one of its latest reports, the World Tourism Organization expressed its concern on "overtourism" (UNWTO, 2019). It turned out that tourism is violently interfering into the residents' habitat, which may cause discomfort, overloads of the natural places of interest and infrastructure. Henceforth, tourism industry should provide benefits for the local communities, while regional experience industry must be developed with regard to the needs of both the visitors and the locals. Special attention should be paid to segmentation of the visitors. Moreover, it should be emphasized that tourism should not violate the social and cultural environment. It raises the question on tourism can influence the sociocultural environment. According to cultural psychology researchers, each community hold its own memory, communication, evaluation, and choice model (Shweder, 1999; Wagoner, 2014). Thus, it is important to understand, whether the tourist traffic triggers any change in the cognitive process model of the local population. Constant tourist flows bring new patterns of cultural behaviour. In fact, tourism is becoming a trigger for changing the behavioural model of the locals. The presumable changes in the labour preferences of the residents are of special interest. As far as the individual general utility function has extended beyond its usual limits to the happiness concept, the importance of life satisfaction expanded to the area of behavioural economics. In contemporary studies, significant behaviour trends are associated with the concept of happiness (Lane, 2017). Therefore, the awareness of self-assessment trends is of special relevance now.

The study focuses on changes in the job satisfaction model of the local population under the influence of regional tourism development as an exogenous variable.

Job satisfaction model: theoretical framework. Using econometric terminology, all job satisfaction studies can be divided into two groups: the ones studying job satisfaction as a dependent variable, and the ones studying it as a predictor.

In the framework of the empirical studies from the first group, it was proved, particularly, that job satisfaction rather depends on the external factors than personal qualities. The external factors include interest in work, satisfaction with professional achievements, relationships with peers and management, working conditions (labour satisfaction index parameters). Personal traits include emotional stability, sociability, and straightforwardness (Vecherin, 2011). Moreover, job satisfaction is explained by the state of family relationships through depression and health, considered as intermediate variables (Sandberg et al., 2012).

Job satisfaction is also influenced by differences in the perception of work: those who see work as a vocation, rate their job satisfaction higher than those who take their work as a career. In their turn, the latter demonstrate higher overall job satisfaction rate, than those who see their work as a routine (Lan et al., 2013). The job satisfaction models also are developed on the basis of satisfaction with the organization's prestige and its social significance (Ivanova et al., 2012).

Cross-country comparisons revealed that higher level of economic development, tertiary sector increase, and protestant ethics can positively affect job satisfaction. Human capital has an ambiguous influence, since a higher level of education can provoke greater demands on working conditions (Monusova, 2008).

Recent labour satisfaction surveys focus on cross-sectoral research, combining the sector of industrial relations with social development of households. The negative impact of absolute monetary, relative non-monetary and subjective monetary poverty on the labour satisfaction of household members has been revealed (Bobkov and Matveyeva, 2014). Besides, the equal need for emotional support in personal life and control at the workplace, together with support from management, to increase satisfaction with the work-life balance, has been determined. Emotional support at the workplace has a complementary effect (Abendroth and den Dulk, 2011). It was found that national culture has an influence over the relationship between work-life balance, job and personal life satisfaction. In individualistic cultures, increasing satisfaction with the work-life balance raises job satisfaction, while in collectivist countries the trend is the opposite: increasing work-life 
balance is followed by negative subjective assessment of labour (Haar et al., 2014).

The studies from the second group drive forward the effect the job satisfaction makes on corporate loyalty (Radford and Meissner, 2017). A lower personal assessment of working conditions can change the emotional state and make one lose their confidence in the future, which, together with other factors, generates negative investments in health capital (Suvorova and Rozmainsky, 2019).

The greater majority of studies reveals the effect of job satisfaction on both individual and collective labour productivity. Based on the happy worker concept, low job satisfaction (unhappy worker) is believed to make negative spillover effects, manifested in conscious or unconscious avoidance of work, slower actions, sickness-caused absenteeism, and counterproductive behaviour. The authors of the study establish a correlation between job satisfaction and customer satisfaction, subdivision productivity and company turnover (Böckerman and Ilmakunnas, 2012).

Considering job satisfaction as an indicator of work quality, differences are established between subjective and objective evaluations of job satisfaction when they affect productivity: high productivity does not affect the increase in subjective job satisfaction, but improves objective assessment (Royuela and Suriñach, 2013).

Job satisfaction has become an integral part of many economic studies. An even deeper study of the irrational behaviour of an economic agent mixes volume and cost indicators of labour productivity with self-assessment. In fact, the subject matter is productivity of an individual, not of an employee. The difference comes from understanding labour of an employee as a result of organization, and labour of an individual as a result of his or her social identification, which becomes especially important in the context of the ongoing transition from labour philosophy to life philosophy (Sidorina, 2013).

Given that the prevailing current researches focus on job satisfaction while balancing work and family, with no regard to broader social existence of the individual, including community, leisure, church, sports, and other activities, we would like to expand the toolbox of job satisfaction exogenous models by introducing the factor of relationships between work and tourism.

Introduction of an exogenous variable. Existing papers provide a variety of options to measure the socioeconomic influence of tourism on the territory. One of the most common ones is the assessment of the contribution made by tourism to the gross regional product, taking the multiplier effect of tourism consumption in the related industries into account. Some researchers explain regional effects from the integration potential of the tourism industry through joint modernization projects, foreign economic cooperation, expanding specialization of the region, overcoming negative migration and employment trends (Chernova, 2017). Others find that the tourism industry, based on the principles of self-regulation (goal-setting, the diversity and economic entropy), improves the level of socioeconomic development of individual territories and reduces entropy (Shelomentsev and Golovina, 2011).

Under system approach, tourism industry refers to the environmental subsystem of the tetrad. This type of subsystem is characterized by unlimited time and space, as well as the ability to inter-period stabilization and inter-territorial homogeneity (Kleiner and Rybachuk, 2019). Due to the tourism development, the leisure sector is actively developing. Thus, being the core of the tourism industry, leisure environment is not limited with the space and time of the tourists' stay, therefore, affecting residents.

The influence of leisure environment spreads wider than over the infrastructural change in the territory; it changes the behavioural model of the residents. A new life perception is developing under the influence of the growing tourist traffic. In general, tourists bring new traditions: cultural tourism develops a taste for cultural practices, health tourism increases health awareness, adventure and eco-tourism draws attention to environmental problems. Unwillingly, locals face a different attitude to life and work. People's behaviour may also change due to the need for building a new infrastructure and localizing the tourist flow, which does not always happen in- 


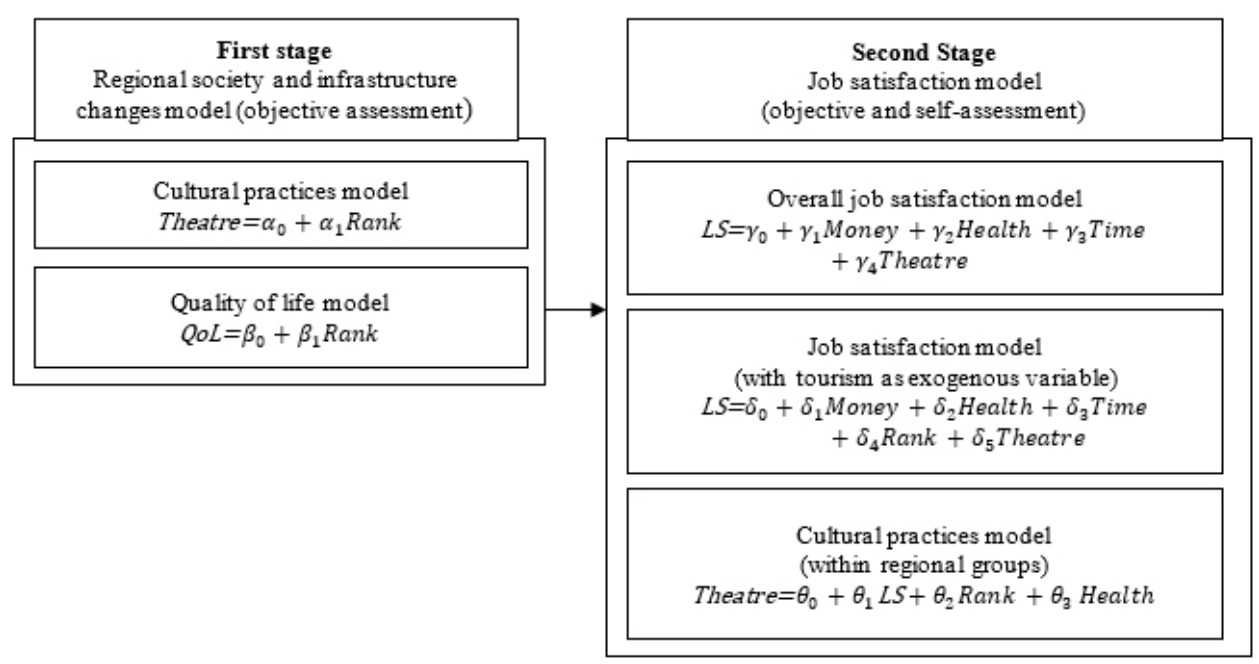

Fig. 1. Logic scheme of the exogenous model of job satisfaction

tentionally. The experience of Corsica shows that tourist-oriented hiking trails forced some changes in the everyday cultural and working practices of the local residents (Melnikova, 2019). Greater availability of leisure forces the local population to change their usual work-leisure ratio. Leisure can change the behavioural model of the residents towards active leisure or a more meaningful attitude to work, transforming the factors of job satisfaction towards avoiding exclusively material ones (wages, bonuses) (Raskov, 2019).

At the same time, there is an ambiguity regarding the impact of leisure on labour productivity. A number of scientific papers refute the relationship between leisure and improving personal performance, while others talk about an inverted U-shaped relationship (Melnikova, 2019). Based on recent research findings, the positive impact of travel on labour productivity has been empirically proven. Travel contributes to the formation of generic skills such as problem solving, time management, communication skills, which, in turn, contribute to human self-efficacy thus enhancing labour productivity (Miyakawa et al., 2019). Despite the fact that in that study the tourist is the subject, the basis for identifying causal relationships is a model of the influence of leisure on personal well-being, including five triggers: restoration through detachment-recovery, autonomy, mas- tery, meaning, and affiliation (Newman et al., 2014). Therefore, the changes in skills and self-efficacy as a result of collision with new situations, people, or events, and not the actual tourist trip, is regarded as the key to productivity improvement. The territory, constantly adapting to tourist preferences, as well as the traffic of tourists carrying new social practices, create a precedent motivating the residents of touristic region to acquire new skills.

Overall data and model structure. The logic scheme in Fig. 1 visualizes the exogenous model of job satisfaction developed by authors of the paper.

The model involves the following variables ${ }^{1}$ : Rank - the position of the region in the Russian Region Tourism Ranking; Theatre the number of theatre visits per 100 inhabitants; $Q o L$ - the position of the region in the Russian Region Quality of Life Ranking; $L S$ - the share of respondents (residents of region) who answered they were "Psychologically quite satisfied with work"; Time - the share of respondents (residents of region) who answered they were: "Quite satisfied with the work schedule"; Money - the share of respondents (residents of region) who answered they were "Quite satisfied with the salary"; Health - the share of

\footnotetext{
${ }^{1} \alpha_{0}, \alpha_{1}, \beta_{0}, \beta_{1}, \gamma_{0}, \gamma_{1}, \gamma_{2}, \gamma_{3}, \gamma_{4}, \delta_{0}, \delta_{1}, \delta_{2}, \delta_{3}, \delta_{4}, \delta_{5}, \theta_{0}, \theta_{1}, \theta_{2}, \theta_{3}-$
} coefficients determined by econometric modelling. 
respondents (residents of region) who selected the answer: "My health is very good."

The changes in the behaviour model of the local residents are studied with respect to the tourism development rate. Modelling is carried out within the rating groups of the Tourism Rating of Russian Regions, based on the growth rate of the most important indicators of the tourism industry (Russiatourism, 2018). This ranking provides a wider understanding of the tourism development of the region, including not only the tourist traffic and number of excursions, but also the availability of hotel rooms, development of tax revenues, employment, investment. Russian regions are divided into five groups: with high $\left(1^{\text {st }}\right.$ group, 10 regions), relatively high ( $2^{\text {nd }}$ group, 11 regions), medium ( $3^{\text {rd }}$ group, 31 regions), relatively low ( $4^{\text {th }}$ group, 22 regions) and low $\left(5^{\text {th }}\right.$ group, 8 regions) tourism development rates.

First, we assume that the dynamics of tourism development in the region make a positive effect on the leisure behaviour model of the residents. As an indicator of leisure time, cultural preferences, namely, the number of theatre visits per 100 inhabitants are used ${ }^{2}$. Based on the existing approaches to the cultural consumption operationalization, the cultural practice analysis allows us to assess the degree of one's involvement in the regional cultural sphere; moreover, such data are quite easy to interpret (Korsunova, 2019). Unlike more tourist-oriented museum practices, theatre practices are popular with a larger share of locals.

Besides, we evaluated the impact made by leisure sphere development on the change in the overall quality of life in a given territory $(Q o L)$. The Quality of Life Ranking of Russian Regions, carried out by RIA ${ }^{3}$, provides an objective assessment of social environment changes.

Secondly, changes in the job satisfaction model under the influence of an exogenous variable and within the framework of constructing

\footnotetext{
2 Open data of the Ministry of Culture of the Russian Federation on the number of spectators of theatres. Available at: https://opendata.mkrf.ru/opendata/7705851331-stat theaters\#a:eyJ0YWIiOiJidWlsZF90YWJsZSJ9 (accessed 05 July 2019).

${ }^{3}$ Available at: https://ria.ru/20190218/1550940417.html (accessed 05 July 2019).
}

subjective-objective models are evaluated. We build an overall job satisfaction model, without tying it to the characteristics of tourism development, and then, a model of change is made. Consequently, it is possible to identify the similarities and differences between the model parameters and draw conclusions about those changes caused by the exogenous variable.

LS, Time, Money, Health, self-assessment variables, are the elements of the Comprehensive Survey on Living Conditions (KOUZ2018) conducted by Rosstat ${ }^{4}$. The model includes variables which, in our opinion, reflect modern approaches defining labour as an economic category and express the logic of our approach, which implies examining job satisfaction through changes in the individual's social environment. Transformation of the work-leisure balance under the change in the work schedule, content and place of work, as well as general erosion of borders have gained prominence in recent studies (Kotliarov, 2019). Therefore, satisfaction with the work schedule (Time) needs to be included into the model as a variable, which explains the effect of expanding the sphere of leisure and the influence of tourist traffic, and forms the ground for labour perception. Due to the fact that tourist intentions focus mostly on healthcare and treatment, the behaviour is associated with increased spending of money, the changes will be also seen in salary satisfaction (Money) and health satisfaction (Health).

First stage results and discussion. The first stage estimates were calculated based on ordinary least squares method (OLS) and presented in Table 1. OLS estimates of the two models revealed compliance with the Fisher and Student criteria. Though, a low level of determination coefficient has been found: 0.05 for the interdependence between tourism development rates and cultural practices and 0.21 for the interdependence between tourism development rates and quality of life. Thus, a nonlinear relationship has been argued.

When testing models for non-linearity based on the Ramsey test for all cases, the p-value turned out to be under 0.05 , which

${ }^{4}$ Available at: http://www.gks.ru/free_doc/new_site/KOUZ18/ index.html (accessed 05 July 2019). 
Igor A. Shevchuk and Tatyana B. Melnikova. Exogenous Model of Job Satisfaction

Table 1. Statistical significance of cultural practices and quality of life models

\begin{tabular}{|c|c|c|}
\hline Variable and criteria & Cultural practices model & Quality of life model \\
\hline Rank & $\begin{array}{c}0.156^{* * *} \\
(0.078)\end{array}$ & $\begin{array}{c}0.396^{* * *} \\
(0.085)\end{array}$ \\
\hline P-value & 0.0499 & 0.0000128 \\
\hline Fisher test & $3.96>$ & $21.64>$ \\
\hline t-test & $1.99>$ & $4.65>$ \\
\hline $\mathrm{R}^{2}$ & 0.05 & 0.21 \\
\hline
\end{tabular}

* Hereinafter: $*-p \leq 0.1, * *-p \leq 0.05, * * *-p \leq 0.01$. Top - variable coefficient, bottom - standard error.

Table 2. Statistical significance of non-linear multiple regressions

\begin{tabular}{|c|c|c|}
\hline \multirow{2}{*}{ Model type } & \multicolumn{2}{|c|}{ Coefficient of determination } \\
\cline { 2 - 3 } & Cultural practices model & Quality of life model \\
\hline Linear & $\mathrm{R}^{2}=0.047$ & $\mathrm{R}^{2}=0.213$ \\
\hline Logarithmic & $\mathrm{R}^{2}=0.030$ & $\mathrm{R}^{2}=0.170$ \\
\hline Quadratic & $\mathrm{R}^{2}=0.123$ & $\mathrm{R}^{2}=0.286$ \\
\hline Cubic & $\mathrm{R}^{2}=0.231$ & $\mathrm{R}^{2}=0.337$ \\
\hline
\end{tabular}

means rejection of the null hypothesis about the models' linearity. In non-linear multiple regressions, cubic dependence has been found to be the closest, based on the determination coefficient (Table 2). However, the wave-like nature of the dependence describes only $23 \%$ of the dependent variable variation.

Based on Fig. 2, we can see upward waves among groups with low and relatively low rates of tourism development, as well as among those with relatively high and high rates. At the average development rate, the behaviour model is differentiated.

Fig. 3, presenting the change in the quality of life under the influence of an exogenous variable, shoes a more conservative scope of fluctuations, but a larger spread of values in the 2nd and 3rd groups (with medium and relatively high rates of development). Social environment development does not keep pace with the creation of leisure environment.

A common feature for the two models is simultaneous improvement of cultural practices and quality of life at low and relatively low rates of development, as well as at high ones. At an average rate of development, the established sources of motivated beliefs and reasoning of the behaviour of an economic agent are shaken. The utility function is assumed not only to depend on the choice between goods and services, but also to be influenced by beliefs. The individual beliefs can be motivated by standards of life, organizations, personality identity, and social identity. Social identity is associated with belonging to a city, ethnic or cultural group, profession (Bénabou and Tirole, 2016). Under the influence of changes in the tourism environment and the increasing traffic of tourists, the beliefs and reasoning of local residents undergo changes to varying degrees; new social groups are formed, cultural preferences are differentiated. A similar situation occurs with the quality of life; however, the cognitive and emotional characteristics of individuals indirectly affect this indicator, mainly through changes in the behaviour of small businesses, attitudes to health, spatial development projects, causing the difference in fluctuations.

Second stage results and discussion. The multiple linear regression for overall job satisfaction model with no regard to the exogenous variable, mostly showed fairly expected results (Table 3).

Changing cultural preferences do not make a direct impact on job satisfaction. Work schedule satisfaction, as well as satisfaction 


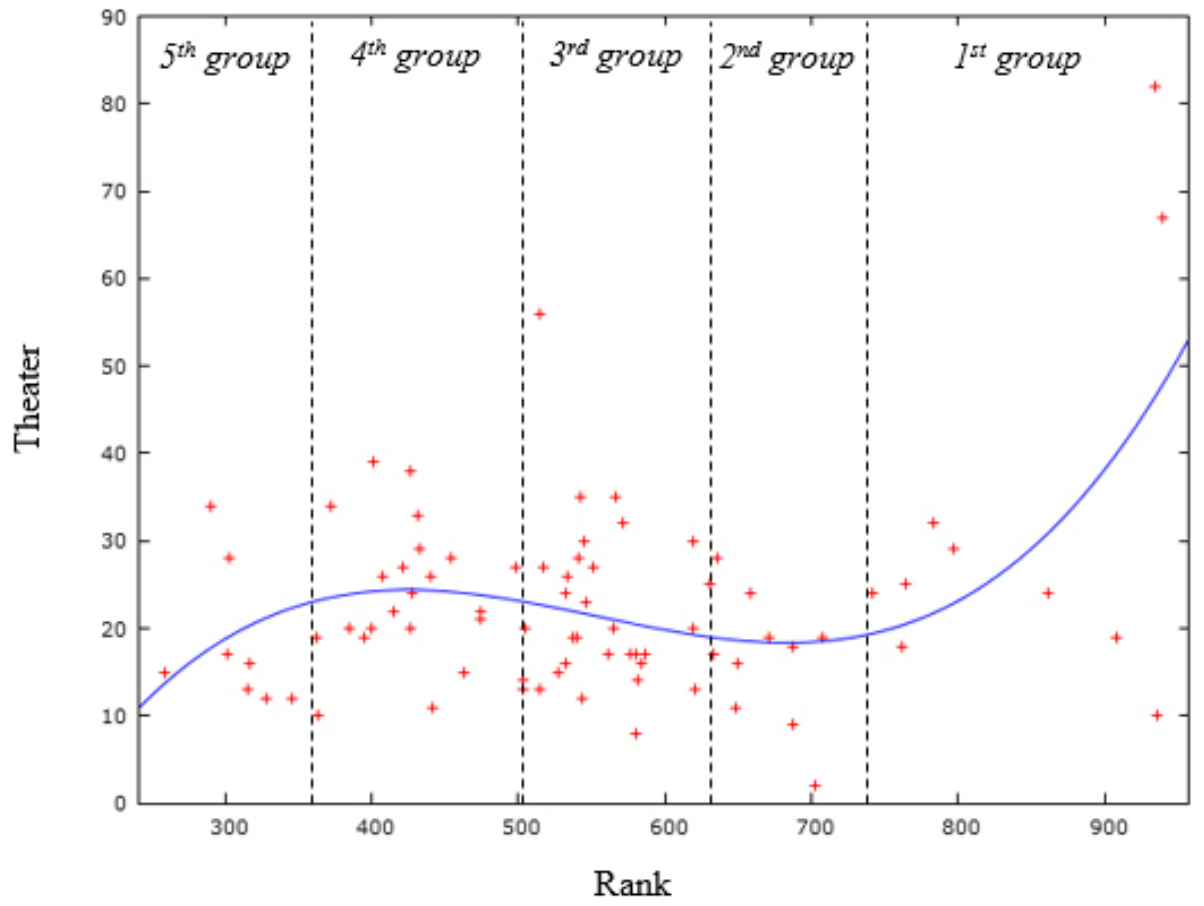

Fig. 2. Changes in cultural practices under different tourism development rates

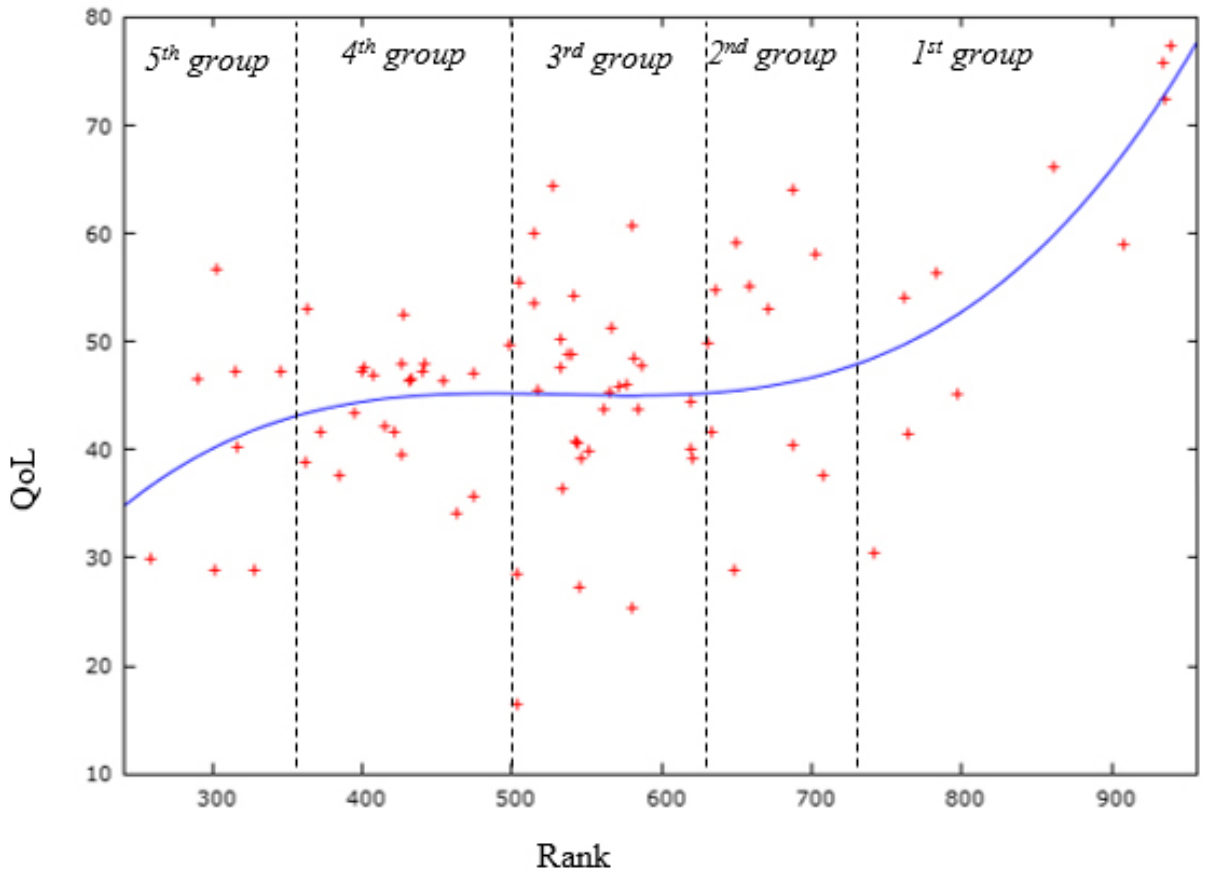

Fig. 3. Changes in quality of life under different tourism development rates 
Table 3. Statistical significance of overall job satisfaction model

\begin{tabular}{|c|c|}
\hline Variable and criteria & Value \\
\hline Money & $\mathbf{0 . 2 5 * * *}$ \\
& $\mathbf{( 0 . 0 8 1 )}$ \\
\hline \multirow{2}{*}{ Health } & $\mathbf{- 0 . 4 4 ^ { * * * }}$ \\
& $\mathbf{( 0 . 1 2 9 )}$ \\
\hline Time & $\mathbf{0 . 4 9 * * *}$ \\
& $\mathbf{( 0 . 1 4 6 )}$ \\
\hline Theatre & - \\
\hline Fisher test & $12.43>$ \\
\hline $\mathrm{R}^{2}$ & 0.32 \\
\hline
\end{tabular}

with salary and health, are the determining factors. The prevailing positive effect is created by work schedule satisfaction.

Analysis of the Health variable raises an interesting situation. Recent survey has shown that health invariably ranks first in the happiness perception of Russians, while stable work is ranked fourth or fifth. The vast majority of Russians consider themselves happy. In general, health status is assessed positively, with the most negative effect on health made by lifestyle and environmental factors (Kiseleva and Strielkowski, 2016). Broadly speaking, arguments should lead to a logical chain linking the two concepts into a single concept of happiness: the higher health satisfaction, the higher work satisfaction. However, the combination of health and work draws us into a balance between work and personal life. The three-component theory details such a balance through a balance of time, a balance of psychological involvement, and a balance of satisfaction. The direct relationship between Time and $L S$ most likely indicates a balance of time. With regard to its sociocultural profile, Russia is more inclined towards a collectivist culture, which implies that in the framework of work-life balance, there is a greater emotional gravitation towards personal life (family life, social activities, leisure, psychological well-being, and healthcare). Thus, for our balance model, psychological imbalance is, in fact, normal. Positive health self-assessment creates a motivation to further expand the sphere of personal life, which increases the imbalance of satisfaction.
A similar paradoxical effect was obtained in recent empirical studies, when it was found that the importance of health for women is inversely related to life satisfaction. This result is explained by the fact that healthcare activities become important for women's well-being only when actually face problems with it (Mospan et al., 2016).

Table 4 displays the results of multiple linear regression by rating groups. For all groups except the second, the Fisher criterion fit well, heteroskedasticity and multicollinearity are not found, non-linearity is not manifested.

There are several critical trends in intergroup trends that should be emphasized.

Firstly, changes in the leisure environment are accompanied by gradual weakening of material values as a factor of work satisfaction. So, the coefficient for the Money variable for the 5 th group, characterized by low rates of tourism development, equals 0.83 , then for regions with average rates it decreased to 0.53 , further, for the first two groups, salary satisfaction has no impact on job satisfaction.

Secondly, the inverse correlation between health perception and psychological satisfaction from work decreases with the growth of tourism (for the fifth and third groups). As regional tourism industry and tourist traffic develop, the local population is forming a new outlook on leisure activities, which makes an effect on psychological health. In the first, second and fourth groups, the health factor is not significant.

Thirdly, cultural practices are significant for job satisfaction only in the fifth group, 
Igor A. Shevchuk and Tatyana B. Melnikova. Exogenous Model of Job Satisfaction

Table 4. Statistical significance of job satisfaction model (with tourism as exogenous variable)

\begin{tabular}{|c|c|c|c|c|c|}
\hline Variable and criteria & $1^{\text {st }}$ group & $2^{\text {nd }}$ group & $3^{\text {rd }}$ group & $4^{\text {th }}$ group & $5^{\text {th }}$ group \\
\hline Money & $\begin{array}{c}0.144 \\
(0.084)\end{array}$ & $\begin{array}{c}0.17 \\
(0.263)\end{array}$ & $\begin{array}{c}0.53 * * * \\
(0.121)\end{array}$ & - & $\begin{array}{l}0.83 * * \\
(0.107)\end{array}$ \\
\hline Health & $\begin{array}{c}1.75 \\
(1.226)\end{array}$ & $\begin{array}{c}1.60 \\
(1.099)\end{array}$ & $\begin{array}{c}-0.87 * * * \\
(0.170)\end{array}$ & - & $\begin{array}{l}-1.52 * * \\
(0.306)\end{array}$ \\
\hline Time & $\begin{array}{c}1.35^{*} \\
(0.544)\end{array}$ & $\begin{array}{l}-0.085 \\
(0.412)\end{array}$ & $\begin{array}{l}0.58 * * \\
(0.223)\end{array}$ & $\begin{array}{c}0.81 * * * \\
(0.249)\end{array}$ & $\begin{array}{c}-0.95 * * \\
(0.174)\end{array}$ \\
\hline Rank & $\begin{array}{c}-0.42 * * \\
(0.147)\end{array}$ & $\begin{array}{c}-0.176 \\
(0.820)\end{array}$ & - & $\begin{array}{c}-0.67 * * \\
(0.272)\end{array}$ & $\begin{array}{c}-0.27 \\
(0.155)\end{array}$ \\
\hline Theatre & $\begin{array}{c}-0.08 \\
(0.085)\end{array}$ & $\begin{array}{c}0.50 \\
(0.442)\end{array}$ & - & - & $\begin{array}{l}0.40 * * \\
(0.082)\end{array}$ \\
\hline $\mathrm{R}^{2}$ & 0.87 & 0.46 & 0.63 & 0.50 & 0.97 \\
\hline
\end{tabular}

which can be explained by the fact that the leisure sphere is not yet developed and is limited to several positions, among which the theatre is the most important. In further groups, leisure is more diversified, so the contribution of the theatre is not critical.

Fourthly, some groups show an inverse correlation between the intra-group rating and job satisfaction, but the value of the coefficient decreases.

The least prominent factor was work schedule satisfaction. In the original model, an increase in the share of the population satisfied with their work schedule by $1 \%$ could cause an increase in the share of the population satisfied with work by $0.49 \%$. Broken by groups, it turned out that at high rates of tourism development, such growth could even exceed $1.35 \%$. However, the wave-like nature of this dependence is fair: from the fifth to the fourth group the coefficient changes its sign, and then, for the third group, the influence decreases from 0.81 to 0.58 , then again grows to 1.35. Perhaps, the effect of adaptation and social comparison is triggered. These two effects explain Easterlin's paradox: as incomes are rising, satisfaction with life and financial situation hardly change. According to the comparison, an individual's satisfaction may depend on the income of the surrounding people. The adaptation effect deals with adapting to changes when, for example, additional income brings little increase in life satisfaction (Larin and Filiasov, 2018).
We then suppose, that work schedule satisfaction means satisfaction with the work-leisure balance. In the fifth group, we observe a situation where job satisfaction is ensured by salary satisfaction and the ability to attend theatres. This positive effect is much stronger than the imbalance between work and leisure, which possibly gravitates to long hours of rest. Further development of tourism provokes individual changes in the structure of employment and expands opportunities for leisure, which changes the sign of the coefficient with variable work schedule satisfaction. However, with increasing flow of tourists, the differentiation of involvement in leisure activities gives rise to a social comparison, which reduces perception of sufficient balance between work and leisure. The higher growth rates, the adaptation effect is triggered through getting used to the flow of tourists, accompanied by the constant updating of leisure programs; the desire to have a sufficient rest grows even more. It may even be referred to as development of a more individualistic approach to life.

Table 5 displays the results of a linear model of multivariate regression for changes in cultural practices by rating groups. In the models of all groups, heteroskedasticity and multicollinearity are absent; for the first and second groups, the Fisher criterion is fulfilled.

In groups with high and relatively high rates of tourism development, changes in cultural preferences are fixed under the influence of moral satisfaction with work and feeling 
Table 5. Statistical significance of cultural practices model (within regional groups)

\begin{tabular}{|c|c|c|c|c|c|}
\hline Variable and criteria & $1^{\text {st }}$ group & $2^{\text {nd }}$ group & $3^{\text {rd }}$ group & $4^{\text {th }}$ group & $5^{\text {th }}$ group \\
\hline \multirow{2}{*}{$L S$} & $\mathbf{3 . 7 1 * *}$ & $\mathbf{0 . 6 3}$ & 0.08 & 0.31 & 1.18 \\
& $\mathbf{( 1 . 4 6 0 )}$ & $\mathbf{( 0 . 3 1 8 )}$ & $(0.224)$ & $(0.268)$ & $(1.544)$ \\
\hline \multirow{2}{*}{ Rank } & - & - & 0.09 & -0.11 & 0.46 \\
& & $(0.138)$ & $(0.277)$ & $(0.331)$ \\
\hline \multirow{2}{*}{ Health } & $\mathbf{8 . 4 7 * * *}$ & $\mathbf{- 2 . 6 1 * * *}$ & -0.28 & -0.23 & -1.14 \\
& $\mathbf{( 2 . 0 6 2 )}$ & $\mathbf{( 0 . 6 3 6 )}$ & $(0.313)$ & $(0.262)$ & $(1.666)$ \\
\hline $\mathrm{R}^{2}$ & 0.76 & 0.68 & 0.08 & 0.09 & 0.38 \\
\hline
\end{tabular}

healthy. At higher stages, as tourist territories develop, work satisfaction increases the theatre visit frequency. The sign at the Health coefficient changes from negative to positive. Apparently, under the influence of extended leisure sphere, mental and social health begins to prevail over physical in the model of human health.

Conclusion. The study presents an exogenous model job satisfaction, built through assessment of the impact made by development of tourism in the region, forming a new system of leisure and behaviour of residents.

At the first stage, the hypotheses regarding the positive impact of the regional tourism development rate on changing cultural practices and the quality of life were considered. Based on objective data, econometric modelling was performed. A cubic correlation between the theatre attendance per 100 inhabitants and the tourism development was revealed, as well as between the quality of life and tourism development. The dynamics of cultural preferences increases with the growth of tourist activity, however, crossing the middle line, its decrease occurs due to the differentiation of leisure preferences of locals. For the quality of life, the average development rate also appears as a period of "decrease in the model significance", however, starting from the 2 nd group, the quality of life grows under the influence of tourism.

At the second stage, work satisfaction modelling was conducted on the basis of linear multivariate regression, carried out on the basis of a subjective-objective data and within each of the rating groups. Work satisfaction with no regard to the exogenous variables of tourism and leisure development is directly affected by work schedule and salary satisfaction, where the former is more than one and a half times stronger than the latter, and, on the opposite, affected by health satisfaction. The opposite correlation between health and job satisfaction is explained mainly by the collectivist culture of Russia, characterized by a psychological gravitation towards personal life (family values, health protection) with a balance between work and personal life.

The change in the work satisfaction model under the influence of such exogenous variable as the growing tourism rate, manifests itself in decreasing significance of the wage factor, a weakening inverse dependence on health satisfaction, a wave-like effect of satisfaction with the work regime under the influence of the social effect and then the adaptation effect.

\section{References}

Abendroth, A-K., den Dulk, L. (2011). Support for the Work-Life Balance in Europe: The Impact of State, Workplace and Family Support on Work-Life Balance Satisfaction. In Work, Employment and Society, 25(2), 234-256. DOI: 10.1177/0950017011398892

Bénabou, R., Tirole, J. (2016). Mindful Economics: The Production, Consumption and Values of Beliefs. In Journal of Economic Perspectives, 30(3), 141-164. DOI: 10.1257/jep.30.3.141

Bobkov, V.N., Matveyeva, T.A. (2014). Vliianie monetarnoy i nemonetarnoy bednosti domokhoziaystv ekonomicheski aktivnogo naseleniia na udovletvorennost' trudom [The Influence of Mone- 
tary and Non-Monetary Poverty of Economically Active People's Households on Job Satisfaction]. In Ekonomika regiona [Economy of Region], 4, 93-104.

Böckerman, P., Ilmakunnas, P. (2012). The Job Satisfaction-Productivity Nexus: a Study Using Matched Survey and Register Data. In ILR Review, 65(2), 244-262. DOI: 10.1177/001979391206500203

Chernova, O.A. (2017). Integratsionnyy potentsial industrii turizma v modernizatsionnom razvitii regiona [The Integration Potential of the Tourism Industry in the Modernization Development of the Region]. In Servis v rossii i za rubezhom [Service in Russia and Abroad], 11 (1 (71)), 125-136. DOI: 10.22412/1995042X-11-1-11

Haar, J.M., Russo, M., Sune, A., Ollier-Malaterre, A. (2014). Outcomes of Work-Life Balance on Job Satisfaction, Life Satisfaction and Mental Health: a Study Across Seven Cultures. In Journal of Vocational Behaviour, 85(3), 361-373. DOI: 10.1016/j.jvb.2014.08.010

Ivanova, T.Iu., Rasskazova, E.I., Osin, E.N. (2012). Struktura i diagnostika udovletvorennosti trudom: razrabotka i aprobatsiia metodiki [Structure and Diagnostic of Job Satisfaction: Development and Approbation]. In Organizatsionnaia psikhologiia [Organizational Psychology], 2 (3), 2-15.

Kiseleva, L.S., Strielkowski, W. (2016). Vospriiatie schastia rossiianami [Perception of Happiness by Russians]. In Sotsiologicheskie issledovaniia [Sociological Studies], (1), 86-91.

Kleiner, G.B., Rybachuk, M.A. (2019). Sistemnaia sbalansirovannost' ekonomiki Rossii: regionalnyi razrez [System Balance of the Russian Economy: Regional Perspective]. In Ekonomika Regiona [Economy of Region], 15 (2), 309-323. DOI: 10.17059/2019-2-1

Korsunova, V.I. (2019). Kulturnoe potreblenie v sotsiologicheskikh issledovaniiakh obzor podkhodov $\mathrm{k}$ izmereniiu poniatiia [Cultural Consumption in Sociological Research: A Review of Measurement Approaches]. In Ekonomicheskaia sotsiologiia [Economic Sociology], 20 (1), 148-166.

Kotliarov, I.D. (2019). Transformatsiia balansa mezhdu trudom i dosugom problem metodologii [Transformation of the Balance Between Labour and Leisure: Problems of Methodology]. In Trudy 8 Mezhdunarodnoy Konferentsii "Trud i dosug" [Proc. 8th Int. Conf. "Labour and leisure"]. Saint-Petersburg, 55-56.

Lan, G., Okechuku, C., Zhang, H., \& Cao, J. (2013). Impact of Job Satisfaction and Personal Values on the Work Orientation of Chinese Accounting Practitioners. In Journal of Business Ethics, 112(4), 627-640. DOI: $10.1007 / \mathrm{s} 10551-012-1562-5$

Lane, T. (2017). How Does Happiness Relate to Economic Behaviour? A Review of Literature. In Journal of Behavioural and Experimental Economics, (68), 62-78. DOI: 10.1016/j.socec.2017.04.001

Larin, A.V., Filiasov, S.V. (2018). Paradoks Isterlina i adaptatsiia v Rossii [Adaptation and the Easterlin Paradox in Russia]. In Ekonomicheskiy zhurnal Vysshey Shkoly Ekonomiki [HSE Economic Journal], 22 (1), 59-83. DOI: 10.17323/1813-8691-2018-22-1-59-83

Mel'nikova, T.B. (2019). Sootnoshenie truda i dosuga v ekonomike regiona [Labour and Leisure Ratio in the Regional Economy]. In Trudy Vserossiyskoy Konferentsii "Ekonomika regionov Rossii: sovremennoe sostoianie i prognoznye perspektivy" [Proc. Rus. Conf. of the REUP Ivanovo branch "Economy of Russian Regions: Current State and Forecast"], Ivanovo, 49-53.

Melnikova, T.B. (2019). Formirovanie i razvitie turistskikh trop vo Frantsii [Development of Tourist Trails in France]. In Uchenye Zapiski Krymskogo Federal'nogo Universiteta imeni V.I. Vernadskogo. Geografiia. Geologiia [Scientific Notes of the V.I. Vernadsky Crimean Federal University. Geography. Geology], 5 (1), 19-27.

Miyakawa, E., Kawakubo, A., Oguchi, T. (2019). Do People Who Travel More Perform Better at Work? In International Journal of Tourism Research, 21, 427-436. DOI: 10.1002/jtr.2269

Monusova, G. (2008). Udovletvorennost' trudom: mezhstranovye sopostavleniia [Job Satisfaction: Cross-Country Comparisons]. In Mirovaia ekonomika i mezhdunarodnye otnosheniia [World Economy and International Relations], 12, 74-83.

Mospan, A.N., Osin, E.N., Ivanova, T.Iu., Rasskazova, E.I., Bobrov, V.V. (2016). Balans raboty i lichnoi zhizni u sotrudnikov rossiyskogo proizvodstvennogo predpriiatiia [Work-Life Balance in Russian Production Enterprise Employees]. In Organizatsionnaia psikhologiia [Organizational Psychology], 6 (2), 8-29. 
Newman, D. B., Tay, L., \& Diener, E. (2014). Leisure and Subjective Well-Being: A model of Psychological Mechanisms as Mediating Factors. In: Journal of Happiness Studies, 15, 555-578. DOI: 10.1007/ s10902-013-9435-X

Radford, K., Meissner, E. (2017). Job Satisfaction and Intention to Stay Within Community and Residential Aged Care Employees. In Australian Journal on Ageing, 36(3), E1-E6. DOI: 10.1111/ajag.12416

Raskov, D. (2019). Len' i trud: po motivam Malevicha [Laziness and Labour: Variations on a Malevich Theme]. In Logos [Logos], 29 (1), 259-272.

Royuela, V., Suriñach, J. (2013). Quality of Work and Aggregate Productivity. In Social Productivity Research, 113(1), 37-66. DOI: 10.1007/s11205-012-0081-1

Russiatourism (2018). Available at: https://www.mkrf.ru/documents/doklad-o-sostoyanii-i-razvitiiturizma-v-2017-godu/ (accessed: 17 July 2019).

Sandberg, J.G., Yorgason, J.B., Miller, R.B., \& Hill, E.J. (2012). Family-to-Work Spillover in Singapore: Marital Distress, Physical and Mental Health, and Work Satisfaction. In Family Relations, 61(1), 1-15. DOI: $10.1111 / \mathrm{j} .1741-3729.2011 .00682 . x$

Shelomentsev, A.G., Golovina, A.S. (2011). Industriia turizma regiona v kontekste printsipov samoregulirovaniia regionalnykh sotsialno-ekonomicheskikh sistem [The Tourism Industry of the Region in the Context of the Principles of Self-Regulation of Regional Socioeconomic Systems]. In Ekonomika regiona [Economy of Region], 1, 166-170.

Shweder, R. (1999). Why Cultural Psychology? In Ethos, 27(1), 62-73.

Sidorina, T. Yu. (2013). Vopros o trude i smysle zhizni [The Issue of Labour and the Meaning of Life]. In Voprosy filosofii [Problems of Philosophy], 11, 3-14.

Suvorova, O.V., Rozmainsky, I.V. (2019). Neverie v budushchee i negativnye investitsii v capital zdorov'ia v Rossii serediny 2010kh godov: issledovanie na osnove oprosa [Disbelief in the Future and Negative Investment in Health Capital in Russia in the mid-2010s: Survey Research]. In TERRA ECONOMICUS [TERRA ECONOMICUS], 17 (1), 41-63. DOI: 10.23683/2073-6606-2019-17-1-41-63

UNWTO (2019). Available at: http://www2.unwto.org/publication/overtourism-understanding-and-managing-urban-tourism-growth-beyond-perceptions-volume-2- (accessed: 17 July 2019).

Vecherin, A.V. (2011). Sub'ektivnye factory udovletvorennosti trudom sotrudnikov organizatsii [Subjective Factors of Job Satisfaction in Organizational Employees]. In Psikhologiia. Zhurnal Vysshei shkoly ekonomiki [Psychology. Journal of the Higher School of Economics], 8 (2), 96-111.

Wagoner, B. (2014). Cultural Psychology and Its Future: Complementarity in a New Key (Niels Bohr Professorship Lectures in Cultural Psychology). Charlotte, Information Age Publishing, 212 p. 


\title{
Экзогенная модель удовлетворенности трудом
}

\section{И.А. Шевчук, Т.Б. Мельникова}

Российский экономический университет имени Г.В. Плеханова,

Севастопольский филиал

Российская Федерачия, Севастополь

\begin{abstract}
Аннотация. Статья вносит вклад в существующие модели удовлетворенности трудом, вводя новую экзогенную переменную - региональное развитие туризма. Туризм не только меняет региональную экономику и инфраструктуру, но также формирует новые культурные практики, отражает пересмотр взглядов людей на здоровье и большую вовлеченность в досуг, вдобавок представляет иные модели принятия решений и суждений. Поэтому авторы предполагают, что в зависимости от темпов развития туризма происходит изменение поведенческой модели жителей. В статье предложено идентифицировать изменения на основе двухэтапного моделирования с помощью множественной линейной и нелинейной регрессии. На первом этапе на основе объективных данных проверена взаимосвязь между развитием туризма и культурной практикой, а также между развитием туризма и качеством жизни. Выявлено, что низкие темпы роста туризма вызывают рост как культурных практик, так и качества жизни, однако в дальнейшем при средних темпах роста мотивированные убеждения в поведении жителей начинают формировать разрозненные представления о досуге. На втором этапе добавлена самооценка жителей для построения общих и внешних моделей удовлетворенности трудом. Под влиянием экзогенной переменной влияние материального фактора (удовлетворенности заработной платой) на удовлетворенность работой уменьшается, формируется новое отношение к отдыху, которое влияет на изменение психологического здоровья. Результаты показали, что самоощущение достаточности баланса между трудом и отдыхом уменьшается по мере увеличения туристических потоков и срабатывания эффекта социального сравнения. Кроме того, при высоких темпах адаптационный эффект развивается через привыкание к потокам туристов и сопровождается постоянным обновлением программ досуга, что проявляется в повышенном влиянии удовлетворенности режимом работы на удовлетворенность трудом.
\end{abstract}

Ключевые слова: удовлетворенность трудом, туризм, экономическое поведение, культурные практики, экзогенная модель, досуг, здоровье, производительность труда, режим работы, местный житель.

Научная специальность: 08.00.00 - экономические науки. 